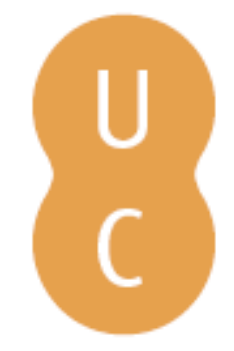

\title{
nommalina
}

\section{A comparison of in-situ fire energy measurements to remote sensed thermography using Unmanned Aerial Systems (UAS)}

\author{
Autor(es): Jimenez, Daniel; Butler, Bret; Queen, Lloyd; Hoff, Valentijn; O’Brien, \\ Joseph; Heirs, J. Kevin
}

Publicado por: Imprensa da Universidade de Coimbra

URL persistente:

URI:http://hdl.handle.net/10316.2/44666

DOI:

DOI:https://doi.org/10.14195/978-989-26-16-506_149

Accessed : $\quad$ 26-Apr-2023 14:16:12

A navegação consulta e descarregamento dos títulos inseridos nas Bibliotecas Digitais UC Digitalis, UC Pombalina e UC Impactum, pressupõem a aceitação plena e sem reservas dos Termos e Condições de Uso destas Bibliotecas Digitais, disponíveis em https://digitalis.uc.pt/pt-pt/termos.

Conforme exposto nos referidos Termos e Condições de Uso, o descarregamento de títulos de acesso restrito requer uma licença válida de autorização devendo o utilizador aceder ao(s) documento(s) a partir de um endereço de IP da instituição detentora da supramencionada licença.

Ao utilizador é apenas permitido o descarregamento para uso pessoal, pelo que o emprego do(s) título(s) descarregado(s) para outro fim, designadamente comercial, carece de autorização do respetivo autor ou editor da obra.

Na medida em que todas as obras da UC Digitalis se encontram protegidas pelo Código do Direito de Autor e Direitos Conexos e demais legislação aplicável, toda a cópia, parcial ou total, deste documento, nos casos em que é legalmente admitida, deverá conter ou fazer-se acompanhar por este aviso.

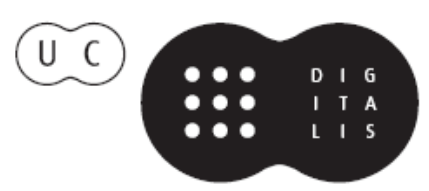




\section{ADVANCES IN}

\section{FOREST FIRE RESEARCH}

\section{8}

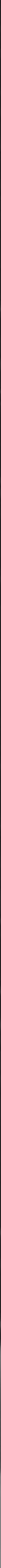


Short contribution - Fire Management

\title{
A comparison of in-situ fire energy measurements to remote sensed thermography using Unmanned Aerial Systems (UAS)
}

\author{
Daniel Jimenez ${ }^{1}$; Bret Butler ${ }^{1}$; Lloyd Queen²; Valentijn Hoff²; Joseph O’Brien ${ }^{3}$; J. Kevin Heirs ${ }^{4}$ \\ ${ }^{I}$ Fire Science Laboratory, Rocky Mountain Research Station, USDA Forest Service, Missoula, Montana, \\ USA, \{djimenez@fs.fed.us*\} \\ ${ }^{2}$ National Center for Landscape Fire Analysis, University of Montana, Missoula, Montana, USA \\ ${ }^{3}$ Center for Forest Disturbance Science, Southern Research Station, USDA Forest Service, Athens, \\ Georgia, USA \\ ${ }^{4}$ Tall Timbers Research Station \& Land Conservancy, Tallahassee, Florida, USA
}

\begin{abstract}
Fire science and management are often limited by an inability to quantitatively measure and track the properties of wildland fire at their full spatial and temporal scales (Riggan et al. 2004). Direct experimental measurements of the energy, fluid flow, and chemical processes occurring in full-scale wildland fires over a spatial extent are difficult to obtain. Techniques exist to measure the radiant intensity or emissive power of the flame; however, the high temperature and transient nature of naturally burning wildland fires has been limited to just a few localized measurements of fire intensity (Butler et al. 2004). Recent advances in unmanned aerial systems (UAS) and light weight, high resolution sensors provide an opportunity to address the various limitations associated with previous research in landscape scale fire radiative power (FRP) estimates. A series of nine small scale $\left(0.5-1 \mathrm{~km}^{2}\right)$ field experiments were instrumented with multiple horizontal and nadir view fire behavior packages (FBPs) in order to characterize point source fire energy measurements. Additionally, in-situ and remote sensed (UAS) radiometric thermograhy data with collocated at high resolution in space and time. Coordinates of each in-situ location were acquired and pre-loaded into the UAS flight plan to ensure collocation data collects. This paper presents the experimental design and preliminary results with the intent to develop a strong correlation between highly resolved ground based fire energy measurements collacted with UAS remote sensed thermography.
\end{abstract}

Keywords: Fire behavior, thermography, remote sensing, unmanned aerial systems

\section{Introduction}

It is widely recognized that fire science and management are critically limited by an inability to quantitatively measure and track the properties of wildland fire at their full spatial and temporal scales (Riggan et al. 2004). An understanding of the variability and dynamics of fire properties is necessary at both plot and landscape scales for future physics based fire behavior models and land managers alike. Fire management requires either tracking or accurate prediction of fire spread rates, intensity, and spread direction in order to ensure firefighter safety and maintain landscape scale objectives. Accurate assessment of the ecological impacts of fire requires either active monitoring or a means to deduce them post burn.

Direct experimental measurements of the energy, fluid flow, and chemical processes occurring in full-scale wildland fires over a spatial extent are difficult to obtain. Techniques exist to measure the radiant intensity or emissive power of the flame; however, the high temperature and transient nature of naturally burning wildland fires has been limited to just a few localized measurements of fire intensity (Butler et al. 2004). Furthermore; wildland fire radiant energy (FRE) is one of the only measurements of combustion that can be made at wide spatial extents and high temporal and spatial resolutions (O’Brien et al. 2016). 
Small-scale experiments have demonstrated that FRE is linearly related to fuel combusted, but such a relationship has not been shown at the landscape level of prescribed fires (Kremens et al. 2010, Hudak et al. 2016). The difficulty in acquiring total radiative energy of a landscape scale fire requires sufficient sampling over time to integrate the radiative energy from instantaneous measures of the fires radiative power (FRP) (Johnston et al. 2017). Several experiments have attempted to classify FRP from a variety of remote sensed platforms, but lengthy return intervals (hrs - mins) and course scale pixel resolution $(\mathrm{km}-\mathrm{m}$ ) have lead to gaps in the data collection (Riggins et al. 2004, Dickenson et al. 2015, Kremens et a. 2010).

Recent advances in unmanned aerial systems (UAS) and light weight, high resolution sensors provide an opportunity to address the various limitations associated with previous research in landscape scale fire radiative power (FRP) estimates. The use of a multi-rotor UAS equipped with infrared (IR) thermography sensor systems is a unique innovation and logical advance and complement to current ground based technology, and is expected to have significant benefits in sampling efficiency, time, and cost.

\section{Methods}

Here we report the priliminary results of a series nine small scale $\left(0.5-1 \mathrm{~km}^{2}\right)$ field experiments conducted at the Tall Timbers Research Station located in Tallahassee, FL in April 2017. The fuels were representative of heterogenious southern rough that varied in age from 1 to 3 years growth since previous fire introduction. Plots were instrumented with in-situ fire behavior packages (FBPs) (Butler et al. 2010) and nadir view in-situ radiometric thermal imaging systems (O'Brien et al. 2012). Additionally, UAS remote sensed radiometric thermal images were collocated with the in-situ instrumentation to collect highly resolved $(\mathrm{cm})$ thermal data orthorecitified in space and time.

Direct experimental measurements of the radiative energy, fluid flow, and chemical processes occurring in full-scale wildland fires over a spatial extent are difficult to obtain, yet critical for understanding fire variability on the landscape. Field deployable ground-based fire behavior packages (FBPs) and digital video cameras provide point source in-situ, timeresolved measurements of radiant and convective energy transfer from the fire, horizontal and vertical air flow, air temperature, and digital video footage. Multiple horizontal and nadir view FBPs $(n=3-5)$ were deployed randomly through each of the Tall Timbers field study plots and sampled at $10 \mathrm{~Hz}$ (Figure 1). FBPs were arranged in pairs, one horizontal and one nadir view, in an effort to capture total hemispherical radiative power at each point in space and time. Sensors were positioned around coordinate ground control points to allow for georeferencing on the landscape.

Additionally, fine scale $(\mathrm{cm})$ nadir view IR radiometric data was collected in-situ from an $8.2 \mathrm{~m}$ tall tripod design (O'Brien et al. 2012). A long wave infrared (LWIR) themal imaging systems from FLIR Inc. (SC660) mounted atop the tripod systems was used to collect $1 \mathrm{~Hz}$ radiometric in-situ data (Figure 2).

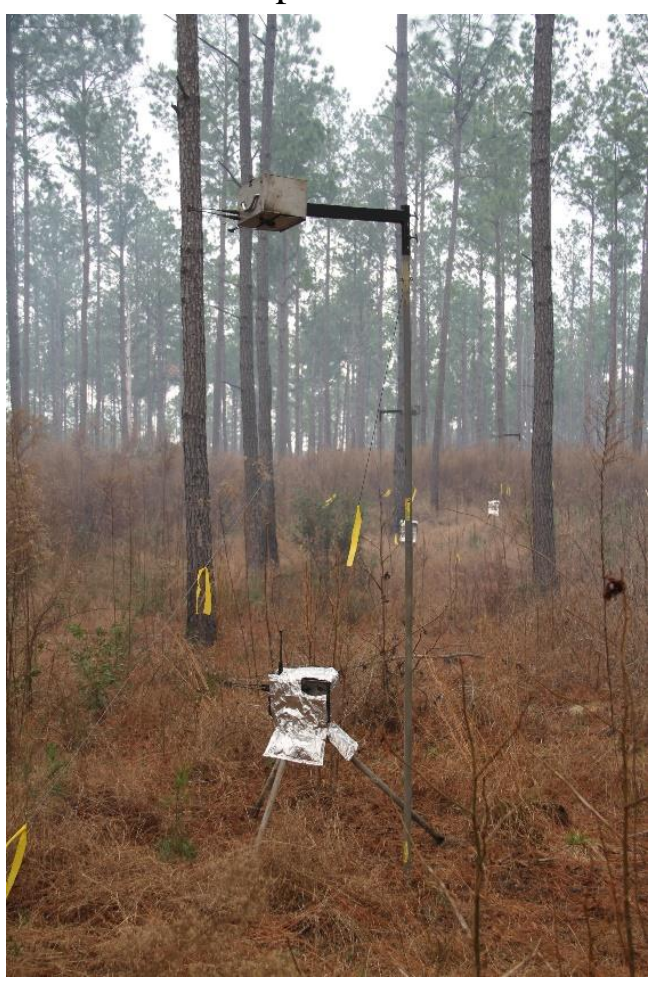

Figure 1 - In-situ horizontal and nadir view FBPs in southern rough fuel type. 
The aerial thermal imagery was acquired using the FLIR Zenmuse XT camera mounted on the DJI matrice UAS platform. The DJI/FLIR combination offers expertise in flight stability, gimbal technology, and image transmission (Figure 3 ). These coupled systems are a fundamental step in linking ground based measurements to nadir radiometric images.

The experimental design was to pre-select areas of interest within each burn unit that would allow for a dual collect (insitu FBP and UAS and tripod thermography) upon ignition. Areas were identified base on fuel characteristics, access, and canopy enclosure. Each in-situ set up consisted of a horizontal mount FBP at $0.5 \mathrm{~m}$ above ground level (AGL), a nadir mount FBP at $3.0 \mathrm{~m}$ AGL, a horizontal GoPro camera at $0.5 \mathrm{~m}$ AGL, a nadir view GoPro housed within the nadir FBP at 3.0 m AGL and one $8.2 \mathrm{~m}$ thermography tripod. The in-situ FBP sensor array was within the measurement footprint of the tripod IR sampling array. Coordinates of each in-situ location were acquired with Real Time Kinematic (RTK) precision positioning system and pre-loaded in the UAS flight plan to ensure collocation data collects.

This approach provided an infrared 2-dimensional temperature profile collocated with in-situ point source fire behavior measurements that are well-understood.

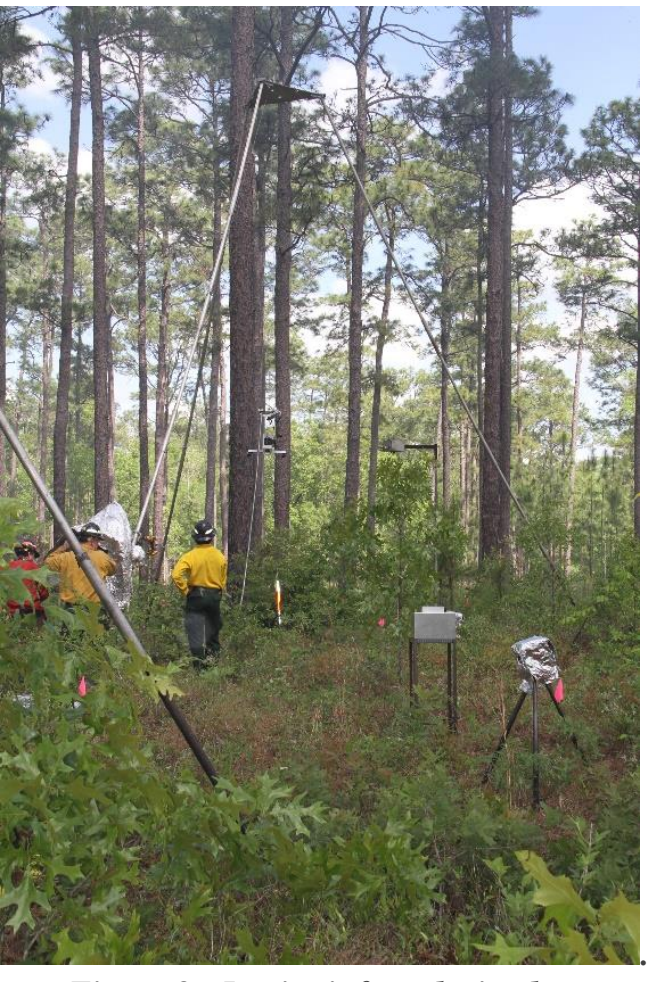

Figure 2 - In-situ infrared tripod system, FPBs and video sensors.

Furthermore, by correlating UAS imagery to in-situ fire energy release, the UAS system acquired data can be calibrated and interpreted in terms of engineering units. The significance of this correlation is that the data become objective, independent of sensor and UAS platform, and quantifiable.

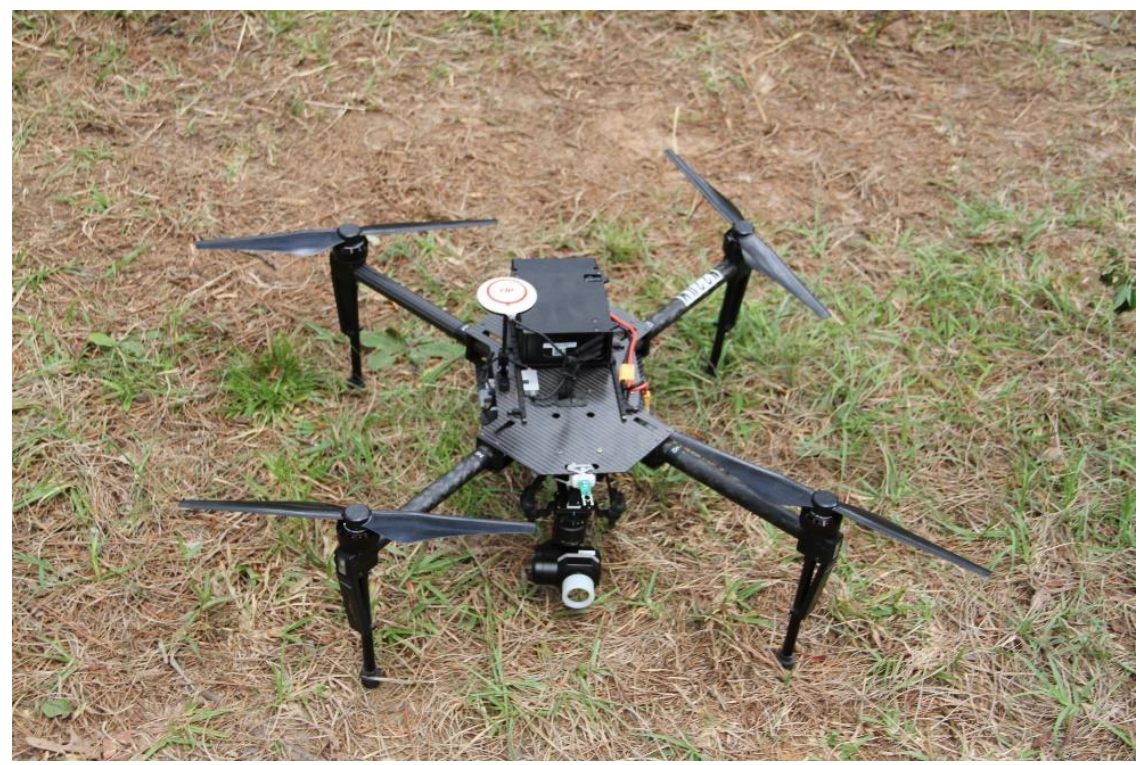

Figure 3 - DJI matrice UAS with FLIR Zenmuse XT infrared camera. 


\section{Results and Discussion}

The experiments were conducted at the Tall Timbers Research Station over the course of three separate burning periods. Physical fire behavior data was collected both in-situ and remotely from various platforms for each of the burn plots. Horizonal and nadir view FBP $10 \mathrm{~Hz}$ data collected radiant and convective heat flux ( $\mathrm{kW} / \mathrm{m} 2)$, horizontal and vertical air flow (mph), and air temperature (C). Addtionally, in-situ nadir view and remote sensed radiometric images were collected at $1 \mathrm{~Hz}$ using a tripod mounted and UAS systems (Figure 4). Ground control points and real time kinematic (RTK) precision positioning systems were used to georeference point source data in space and time.
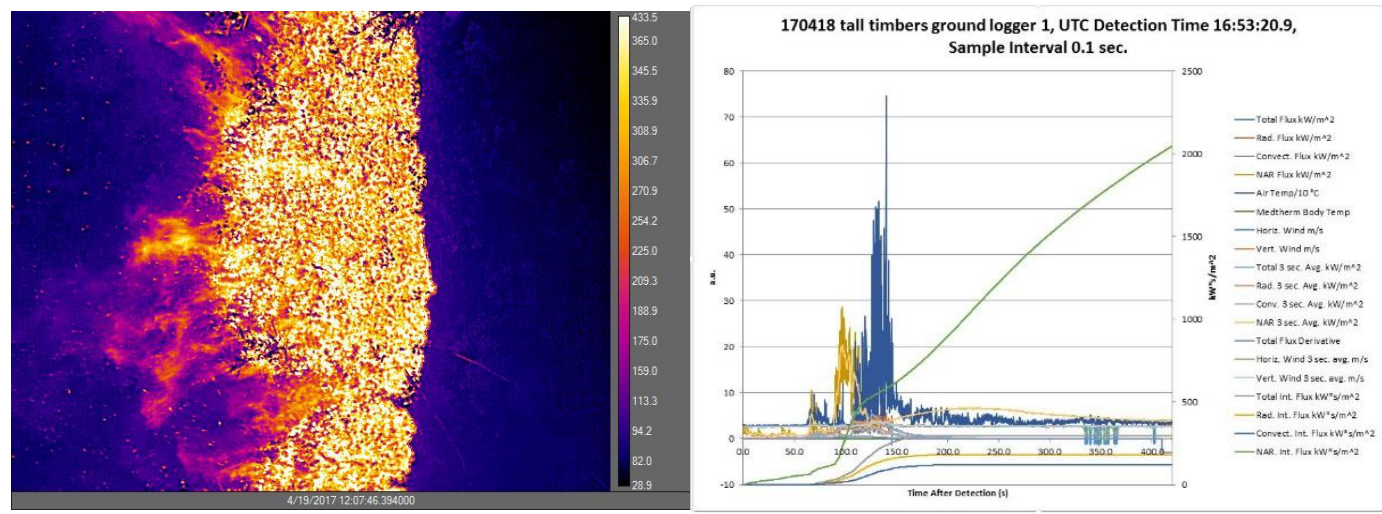

Figure 4 - Radiometric image for UAS platform(left) and data profile from in-situ FBP(right).

This presentation presents the experimental design and primilnary results with the intent to develop a strong correlation between highly resolved ground based fire behavior measurements collocated with UAS remote sensed thermography. The benefits are multifaceted, the primary being demonstrating how data acquired using UAS systems can be used by fire managers to more effectively characterize fire energy release and thereby achieve management objectives. Other benefits include cost savings through reduction in required monitoring activities. This demonstration has the ability to supplement and expand ground based monitoring programs to quantify fire effects, habitat impact, fuel reduction and other management objectives. Other benefits include reduced risk to personnel through improved situational awareness. In-situ and UAS data analysis will provide a benchmark for landscape scale management techniques that will provide natural resource specialists with quantifiable data and tools necessary to analyze pre and post burn imagery.

\section{Acknowledgements}

This work was supported through funding provided from the officeof the US Forest Service Deputy Chief for Research and the University of Montana. The gracious assistance of the Tall Timbers Research Station staff during the experiments is also appriciated.

\section{References}

Riggan, P. J., Tissell, R. G., Lockwood, R. N., Brass, J. A., Pereira, J. A. R., Miranda, H. S., ... \& Higgins, R. (2004). Remote measurement of energy and carbon flux from wildfires in Brazil. Ecological Applications, 14(3), 855-872.

Butler, B. W., Cohen, J., Latham, D. J., Schuette, R. D., Sopko, P., Shannon, K. S., ... \& Bradshaw, L. S. (2004). Measurements of radiant emissive power and temperatures in crown fires. Canadian Journal of Forest Research, 34(8), 1577-1587. 
O'Brien, J. J., Loudermilk, E. L., Hornsby, B., Hudak, A. T., Bright, B. C., Dickinson, M. B., ... \& Ottmar, R. D. (2016). High-resolution infrared thermography for capturing wildland fire behaviour: RxCADRE 2012. International Journal of Wildland Fire, 25(1), 62-75.

Kremens, R. L., A. M. S. Smith, and M. B. Dickinson. "Fire metrology: current and future directions in physics-based methods." Fire Ecology 6.1 (2010): 13-35.

Hudak, A. T., Dickinson, M. B., Bright, B. C., Kremens, R. L., Loudermilk, E. L., O'Brien, J. J., ... \& Ottmar, R. D. (2016). Measurements relating fire radiative energy density and surface fuel consumption-RxCADRE 2011 and 2012. International Journal of Wildland Fire, 25(1), 25-37.

Johnston, Joshua M., et al. "Direct estimation of Byram's fire intensity from infrared remote sensing imagery." International Journal of Wildland Fire 26.8 (2017): 668-684.

Dickinson, M. B., Hudak, A. T., Zajkowski, T., Loudermilk, E. L., Schroeder, W., Ellison, L., ... \& Bright, B. C. (2016). Measuring radiant emissions from entire prescribed fires with ground, airborne and satellite sensors-RxCADRE 2012.

Butler, BW, D Jimenez, J Forthofer, K Shannon, and P Sopko. (2010) A Portable System for Characterizing Wildland Fire Behavior. Paper presented at the Proceedings of the 6th International Conference on Forest in Fire Research.[CD-ROM]. Coimbra, Portugal: University of Coimbra.

O'Brien, Joseph J., et al. "High-resolution infrared thermography for capturing wildland fire behaviour: RxCADRE 2012." International Journal of Wildland Fire 25.1 (2016): 62-75. 